\title{
A Study of Dog Coprolite from Late Neolithic Pile-Dwelling Site in Slovenia
}

\author{
Tjaša Tolar ${ }^{1 *}$, Alfred Galik ${ }^{2}$ \\ ${ }^{1}$ Scientific Research Centre of the Slovenian Academy of Sciences and Arts (ZRC SAZU), Institute of Archaeology, Ljubljana, \\ Slovenia \\ ${ }^{2}$ Austrian Archaeological Institute, Vienna, Austria \\ Email: *tjasa.tolar@zrc-sazu.si
}

How to cite this paper: Tolar, T., \& Galik, A. (2019). A Study of Dog Coprolite from Late Neolithic Pile-Dwelling Site in Slovenia. Archaeological Discovery, 7, 20-29. https://doi.org/10.4236/ad.2019.71002

Received: November 8, 2018

Accepted: January 12, 2019

Published: January 15, 2019

Copyright (C) 2019 by authors and Scientific Research Publishing Inc. This work is licensed under the Creative Commons Attribution International License (CC BY 4.0).

http://creativecommons.org/licenses/by/4.0/

\begin{abstract}
More than 5000 years old dog's coprolite was found during rescue excavation at Črnelnik pile-dwelling site in Slovenia. Although human and dog diets may overlap considerably, the content of the consumed and digested food, consisting of plant and/or animal remains biologically diverse. While the investigated fossil excrement contained many fish head bones, scales and teeth of Cyprinidae family, we believe that we are dealing with an individual that had only eaten fish heads, that is why it was suggested to be of dog. Beside the origin and the daily diet of the individual together with the nutritional habits of the dog in the Late Neolithic, the analyses of coprolite provide more important information, for example: the time of year of the deposit, the environmental conditions there, the size and the health of the animal as well as care (or the status) of domesticated animal for humans. The discovery confirms again that animal dung should be an important part of archaeological investigations, specially at waterlogged sites.
\end{abstract}

\section{Keywords}

Archaeobiology, Nutrition, Late Neolithic, Coprolite, Dog

\section{Introduction}

Archaeobotany and archaeozoology are important natural sciences that supplement archaeological investigations. Both botany and zoology are closely connected to human activities. Nutrition supplies (for people and domesticated animals), as well as material for building activities or weapon and tool production are all connected with natural materials, both plant and animal. Archaeobiological material can be well preserved in waterlogged conditions where organic 
remains are often preserved in an uncarbonised state and in large amounts. Circum-Alpine prehistoric lake-shore settlements are typical such archaeological sites. The Ljubljansko barje region in Slovenia with more than 40 pile-dwelling sites from the 5th to the 2nd millennium cal BC (Velušček, 2004) is the most southeasterly region of those sites (Figure 1).

Archaeological layers of lake-shore pile-dwelling sites are always composed of a variety of components derived from human and animal activity (Jacomet et al., 2004). Well preserved coprolites (fossil excrement remains) can often be found as well (Byrne, 1973; Akeret \& Jacomet, 1997; Kühn et al., 2013). They are found whole or fragmented, uncarbonised and from various animals such as mice, sheep/goats, cattle, dogs etc. as well as from humans. Beside the daily diets of the individuals and their nutritional habits, the analyses of coprolites can provide more important information, for example: the time of year of the deposit, the environmental conditions there, the size and the health of the animal, care (or the status) of domesticated animals for humans, endoparasites if present, and finally also an exact C14 dating of the consumed plant/animal macroremains. The organic material of terrestial plants and animals preserved in waterlogged conditions are one of the most suitable archaeological matter for radiocarbon dating. Therefore animal dung should be an important part of archaeological investigations at waterlogged sites. Goat and sheep faeces have been investigated relatively often because they are compact and, therefore, are not always destroyed by sieving (Akeret \& Jacomet, 1997; Akeret et al., 1999; Kühn et al., 2013). Cattle dung is often a mixture of faeces, stable litter, fodder and material that had nothing to do with cattle management (Kühn et al., 2013). Not so often, but randomly, dog or human coprolites can be found as well, when the excavation is careful and precise (Byrne, 1973). They are compact and therefore easy to

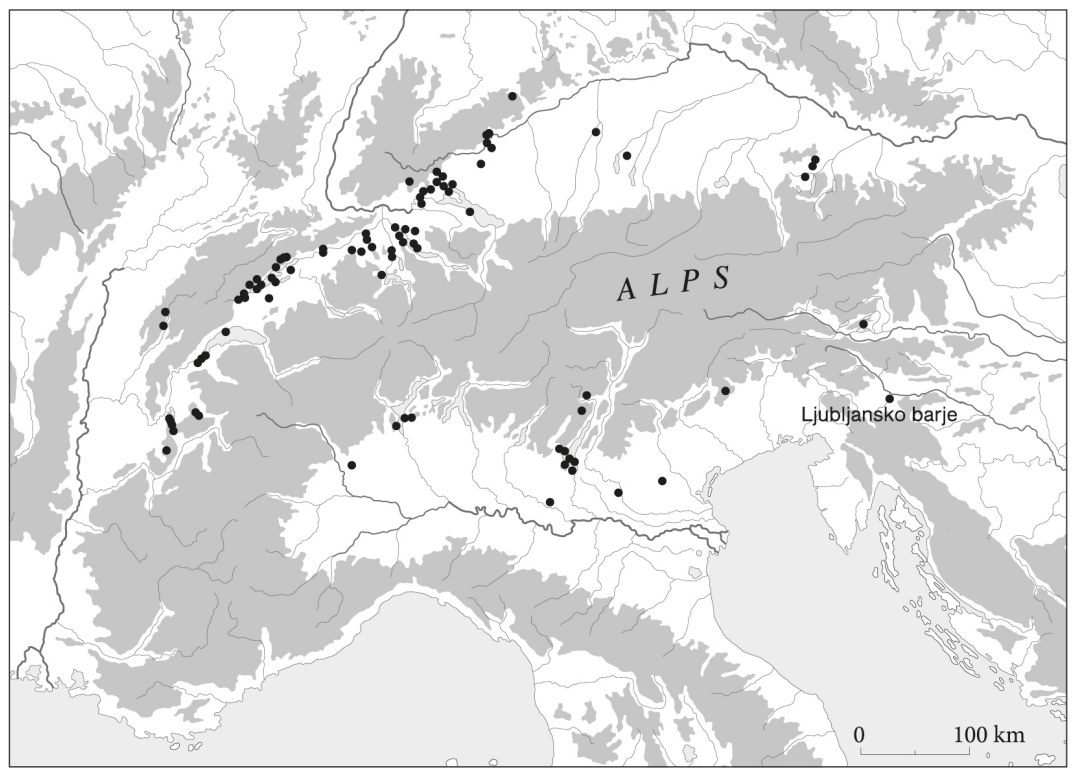

Figure 1. Geographical position of the Ljubljansko barje (longitude: $14^{\circ} 29^{\prime \prime}$; latitude: $\left.46^{\circ} 0^{\prime \prime}\right)$ in the European Circum-Alpine lake-shore (pile-dwelling) sites. 
recognize. While their outer structure and shape are similar to human or pig coprolites, the inner composition may differ (Byrne, 1973). While many studies have been made on goat/sheep faeces in order to investigate prehistoric management of domesticated animals and transhumance (Akeret \& Jacomet, 1997; Akeret et al., 1999; Kühn et al., 2013), dog coprolites have not often been analysed, although the osteological investigations on them show that the dog was an important human companion in the Eneolithic (Bartosiewicz, 1999, 2002). The probable reason for the previous lack of study is that dog coprolites are not so often found.

\section{Materials and Methods}

Presumably dog or human well preserved waterlogged excrement in the cultural layer of the Late Neolithic pile-dwelling site Črnelnik in Slovenia was found in 2014, when the mechanical excavation of the ditch for the sewerage began (Velušček et al., 2018). Excrement of Canis familiaris (dog), as well as of human, mostly show an elongated, sometimes segmented shape (Jones, 1990). Well-preserved specimens are rarely found (Brönnimann et al., 2017). The one from Crnelnik site was dark brown, with a length of ca. $6 \mathrm{~cm}$, and a width of ca. 2-3 cm (Figure 2).

The typical shape, colour and structure suggest that it is of dog or human origin (Byrne, 1973; Harrison, 2011; Brönnimann et al., 2017 and Link-

http://www.scirpus.ca/dung/mammal.php). While the content of the consumed and digested food, consisting of plant and/or animal remains biologically diverse, the content of digested materials was investigated in the archaeobotanical laboratory by the methods of gently disaggregation and washing over $0.056 \mathrm{~mm}$ mesh sieve (following Jouy-Avantin, 2003). Then the macroremains caught on the sieve were sorted out and identified using a Leica MZ75 stereomicroscope with up to 50x magnification, with the aid of the reference collection of the plant remains at the Institute of Archaeology, ZRC SAZU and osteological fish bone reference collection at the Austrian Archaeological Institute. Identification atlases and keys were used as well (Schmid, 1972; Granadeiro \& Silva, 2000; Cappers et al., 2006).

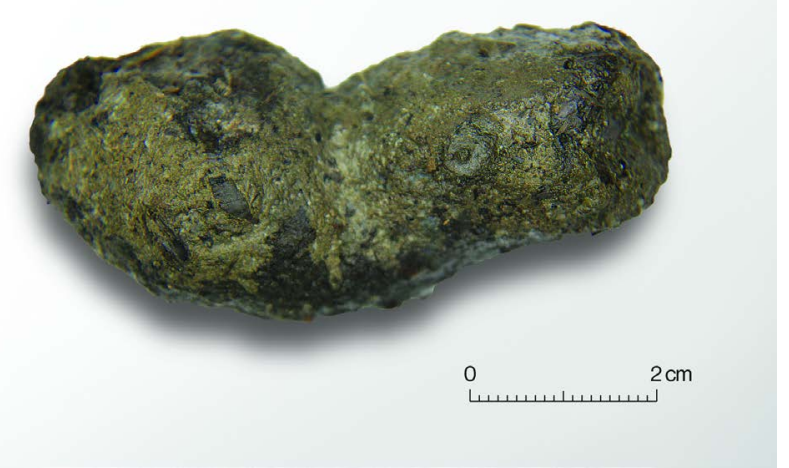

Figure 2. The coprolite from Črnelnik site. Photo: D. Valoh. 


\section{Results and Discussion}

On the first view, the coprolite showed mineralized structure, it was compact, hard and resistant to pressure, therefore it was not easy to disaggregate it. As the coprolite was waterlogged preserved, the remains caught on the sieve were mostly uncarbonised preserved. They were precisely sorted, counted and identified in wet conditions. All togehter, $20 \mathrm{ml}$ of the organic fraction was caught on the sieve. Animal remains, mostly uncountable unidentifiable flat bone fragments and fish scales and pharyngeal teeth of the Cyprinidae family prevailed. Among plant macroremains, six taxa were identified (Table 1; Figure 3). Some very small fragments of charcoal were present as well.

We found out that the specimen (most probably the dog) enjoyed diverse food. The scales, teeth of fish, and uncountable unidentifiable flat-most likely skull bone remains of fish heads, prevailed (Figure 3(a), Figure 3(b)). Interestingly, there were, except of one individual (Figure 3(f)), no fish vertebrates included, indicating that the specimen only fish heads had eaten. Therefore we conclude that the excrement most likely belongs to the dog. Rare plant remains testify that the dog also enriched its menu with vegetable food as well. Jones (1986) established that less than $10 \%$ of ingested bones survived passage through an animal's digestive system: beside some skull and cranial elements, the vertebrae survived as well. Beside the absence of the vertebrae, the absence of larger content of plant macroremains (except individual seeds; Table 1, Figure $3(c)$ ) additionally convinced us that this is most probably dog's excrement. Byrne (1973) has recognized the differences between dog coprolites which contain

Table 1. The content of macroremains in the coprolite from Črnelnik site.

\begin{tabular}{|c|c|}
\hline Number & Content \\
\hline \multicolumn{2}{|c|}{ PLANT REMAINS } \\
\hline 4 seeds & Rubus fruticosus agg. (blackberry) \\
\hline 1 seed & Linum usitatissimum (flax) \\
\hline 3 seeds & Chenopodium album (white goosefoot) \\
\hline 1 seed & Brassica rapa (turnip) \\
\hline 1 seed & Betula sp. (birch) \\
\hline $1 \mathrm{frg}$. of fruit and $1 \mathrm{frg}$. of leaf & Trapa natans (water chestnut) \\
\hline \multicolumn{2}{|c|}{ FISH REMAINS } \\
\hline $\mathrm{x}$ & skull and cranial element fragments \\
\hline $\mathrm{x}$ & pharyngeal teeth of Cyprinidae \\
\hline $\mathrm{x}$ & scales of Cyprinidae \\
\hline 3 fragments & finrays \\
\hline 1 & epihyale \\
\hline 1 fragment & vertebra fish unident. \\
\hline
\end{tabular}

$\mathrm{x}$-many, not counted. 


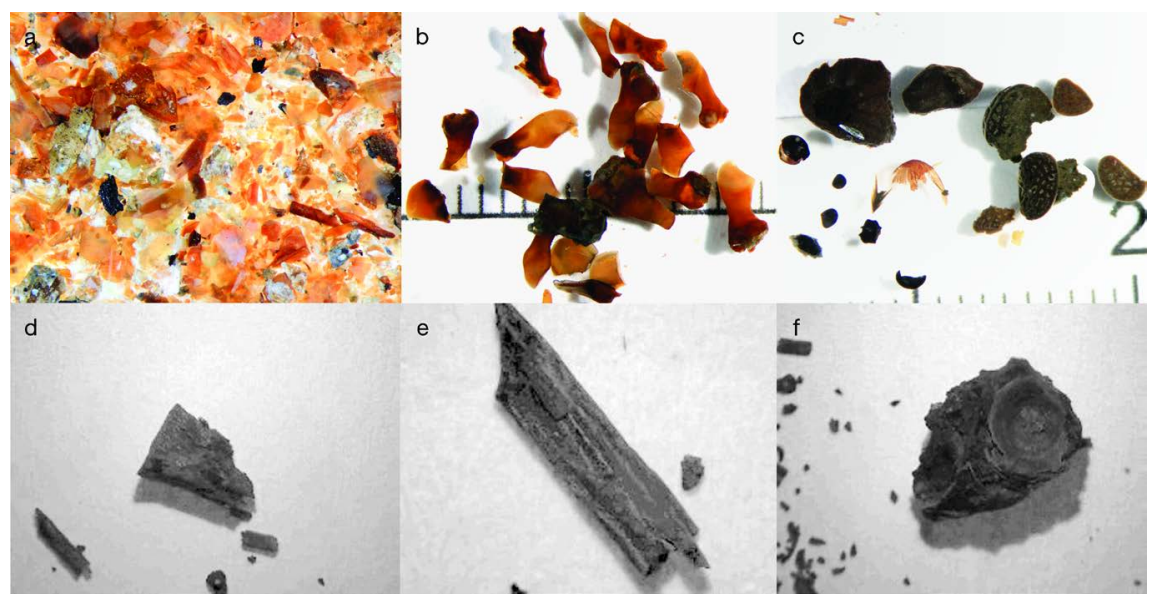

Figure 3. An example of macroremains from the coprolite, after processing in the archaeobotanical laboratory. Numerous flat fish remains, scales (a) and teeth (b), plant macroremains (c), epihyale fragment (d), finray fragment (e) and single vertebra remain (f). Photos: D. Valoh (a-c) and A. Galik (d-f).

mainly fish bone fragments, and human coprolites which contain mainly plant remains. The absence of fur or animal hair suggest that we are neither dealing with a wolf, for which larger content of hairs are typical in the excrement (Skrbinšek, 2010 and Link-

http://www.volkovi.si/wp-content/uploads/2014/10/zimsko-sledenje_navodila-k oncna.pdf).

Beside nutrition habits and the diet of the individual, the preserved macroremains give also other important information. The size (the width) of the excrement suggest that the dog was some smaller than a wolf, for example, which excrement measures about $3 \mathrm{~cm}$ in width, smaller wolfs $2 \mathrm{~cm}$, while the biggest ones up to $4 \mathrm{~cm}$ in width (Skrbinšek, 2010).

Another information gives the remain of birch fruit for example, which extend its seeds from the late summer till the winter time; and also other recognized seeds/fruits (i.e. of water chestnut, flax, turnip, blackberry and goosefoot) are mature in late summer or autumn, what gives the information of the deposit (excrement) period of the year and consequently the settling period, which was most probably permanent (during whole year seasons; Čufar et al., 2010; Tolar et al., 2011).

Ecological conditions at and around the site could be discussed as well. Birch and water chestnut evidence marshy ground and the existence of slow flowing river or a lake, while the others (flax, turnip and goosefoot) evidence fields and other antrophogenic areas (Kreuz \& Schäfer, 2011; Tolar et al., 2011). Fishes of the Cyprinidae family, collectively called cyprinids, that includes carp, true minnow, and their relatives, is the largest known fish family with about 3000 living and extinct species in about 370 genera. Some of the fish remains are isolated pharyngeal teeth (Figure 3(b)) of typical freshwater species like rudd or roach (Kottelat \& Freyhof, 2007).

Predominantly uncarbonised remains of fish heads in the coprolite indicate 
organic refuse management as well. The culture of eating fishes and the importance of the lake for the neolithic economy can be illustrated at various pile-dwelling sites (Torke, 2000; Govedič, 2004; Hüster-Plogmann, 2004; Jacomet et al., 2004; Jörg, 2006; Kottelat \& Freyhof, 2007; Galik, 2009). One of the explanations could be that humans ate fish bodies, while the heads were thrown to dogs (Ewersen \& Schmölcke, 2013), very likely even before roasting, while the fish remains were uncarbonised preserved. More evidences (with more dog coprolite investigations) should be performed to confirm this hypothesis. Aditionally, the care (and the status) of domesticated animal for humans colud be discussed. It seems that dog's master knew that fish heads are safer food for his dog than fish bodies (with lots of peaked bones), what leads to a suspection that humans took care for dogs, what consequently prove that the dog had an important status for humans (Bartosiewicz, 2002; Ewersen \& Schmölcke, 2013; Janssens et al., 2018).

\section{Conclusions}

Coprolites of Canis familiaris (dog) as well as of human are regularly reported in various archaeological contexts (Macphail, 2000; Ismail-Meyer \& Rentzel, 2004 and etc.), but rarely as completely preserved specimens. Therefore dog faeces from the Crnelnik site is valuable and remarkable find that has been worthwhile to investigate. We assume we are dealing with the coprolite of dog origin, because uncarbonised remains of fish heads (teeth, scales and flat bones) of Cyprinids were mainly preserved (Figure 3 ). It would make sense to re-excavate at the Crnelnik site, not only for the possibility of obtaining some more coprolites that are possibly abundant at that site, other archaeological and archaeobiological investigations could also be carried out at the same time, since other very interesting finds have been found at this site (Velušček et al., 2018). The investigation of only one well preserved coprolite sets out to explore the possibilities of coprolite analysis in wetland prehistoric archaeology. The presented initial strategy of investigating macroremains content in the waterlogged faeces is going to be the basis for future researches of newly excavated material (possibly dog or human coprolites) in Slovenia (Ljubljansko barje), as well as at other wetland sites. If more material (i.e. coprolites) available, different possible means of extracting data could be performed, beside plant and animal macroremains, also parasites (which beside biological origin of the sample, brings with it information that relates to many domains: primarily, palaeopathology and sanitary conditions, but also palaeodietetics, organic refuse management and cultures; Bouchet et al., 2003; Le Bailly et al., 2003, 2005), micromorphology (Macphail, 2000; Akeret \& Rentzel, 2001; Ismail-Meyer \& Rentzel, 2004; Brönnimann et al., 2017), pollen (Martin \& Sharrock, 1964; Horrocks \& Irwin, 2003), C14 dating, DNA extraction (Iñiguez et al., 2003) as well as biomarkers (such as lipids and stable isotopes which evidence totally digested food such as dairy products; Gill et al., 2009). All the investigations are intended to provide a range of information about past life in the pile-dwelling settlements, not only about the diet. If more 
canine coprolites investigated, cultural heritage could be discussed as well, for example why the hunter-gatherers kept dogs; were they domesticated dogs and kept only for particular purposes such as helping with hunting, or were they regarded also as pets, and how were they kept, fed and what care or importance were they given (Ewersen \& Schmölcke, 2013; Janssens et al., 2018)?

The presented research is the first investigation of coprolites in Slovenia, the most southeasterly region of Late Neolithic circum-Alpine lake-shore sites, where such finds are not rare. It has an important impact for the development of new research directions there, and on the other hand, it contributes to the database which is already available from comparable prehistoric waterlogged contexts in Europe (Bouchet et al., 2003; Le Bailly et al., 2003; Kühn et al., 2013; Maicher et al., 2017 and Link-http://www.scirpus.ca/dung/mammal.php). While this type of find material is scarce and hard to obtain, and therefore only rarely investigated, each analysis of it counts and is original and exceptional.

\section{Acknowledgement}

The project was financed by the Slovenian Research Agency (funding No. P6-0064 and No. J7-6857). Many thanks to technical assistant Dragotin Valoh for preparing figures and to James Greig for improving the English language.

\section{Conflicts of Interest}

The authors declare no conflicts of interest regarding the publication of this paper.

\section{References}

Akeret, Ö., \& Jacomet, S. (1997) Analysis of Plant Macrofossils in Goat/Sheep Faeces from the Neolithic Lake Shore Settlement of Horgen Scheller-An Indication of Prehistoric Transhumance? Vegetation History and Archaeobotany, 6, 235-239. https://doi.org/10.1007/BF01370444

Akeret, Ö., \& Rentzel, P. (2001) Micromorphology and Plant Macrofossil Analysis of Cattle Dung from the Neolithic Lake Shore Settlement of Arbon Bleiche 3. Geoarchaeology: An International Journal, 16, 687-700. https://doi.org/10.1002/gea.1016

Akeret, Ö., Hass, J. N., Leuzinger, U., \& Jacomet, S. (1999) Plant Macrofossil and Pollen in Goat/Sheep Faeces from the Neolithic Lake-Shore Settlement Arbon Bleice 3, Schwitzerland. The Holocene, 9, 175-182. https://doi.org/10.1191/095968399666631581

Bartosiewicz, L. (1999) Recent Developments in Archaeozoological Research in Slovenia. Arheološki Vestnik, 50, 311-322.

Bartosiewicz, L. (2002) Dogs from the Ig Pile Dwellings in the National Museum of Slovenia. Arheološki Vestnik, 53, 77-89.

Bouchet, F., Harter, S., \& Le Bailly, M. (2003) The State of the Art of Paleoparasitological Research in the Old World. Memorias do Instituto Oswaldo Cruz, 98, 95-101. https://doi.org/10.1590/S0074-02762003000900015

Brönnimann, D., Pümpin, C., Ismail-Meyer, K., Rentzel, P., \& Egüez, N. (2017) Excrements of Omnivores and Carnivores. In: Nicosia, C. and Stoops, G., Eds., Archaeologi- 
cal Soil and Sediment Micromorphology (pp. 67-82). Oxford, UK: Wiley Blackwell. https://doi.org/10.1002/9781118941065.ch7

Byrne, D. (1973) Prehistoric Coprolites: A Study of Human and Dog Coprolites from Prehistoric Archaeological Sites in the North Island of New Zealand. M.A. Thesis, University of Auckland.

Cappers, R., Bekker, R. M., \& Jans, J. E. A. (2006) Digitale Zadenatlas van Nederland (Digital Seed Atlas of the Netherlands). Groningen: Barkhuis Publishing \& Groningen University Library.

Čufar, K., Kromer, B., Tolar, T., \& Velušček, A. (2010) Dating of 4th Millenium BC Pile-Dwellings on Ljubljansko Barje, Slovenia. Journal of Archaeological Science, 37, 2031-2039. https://doi.org/10.1016/j.jas.2010.03.008

Ewersen, J., \& Schmölcke, U. (2013) Untersuchungen zur Haltung und Nutzung von Haushunden auf meso- und neolithischen Fundplätzen im nördlichen Deutschland. Universitätsforschungen zur prähistorischen Archäologie. B. Ramminger, 240, 267-299.

Galik, A. (2009) Die Bedeutung des Fischfangs in der Horgener Seeufersiedlung Wallhausen-Ziegelhütte am Überlinger See, Hemmenhofener Skripte, 8, 138-144.

Gill, F. L., Crump, M. P., Schouten, R., \& Bull, I. D. (2009) Lipid Analysis of a Ground Sloth Coprolite. Quaternary Research, 72, 284-288.

https://doi.org/10.1016/j.yqres.2009.06.006

Govedič, M. (2004) Fishes from the Archeological Site at Hočevarica. In: Velušček, A., Ed., Hočevarica-An Eneolithic Pile Dwelling in Ljubljansko Barje, Opera Instituti Archaeologici Sloveniae, 8, 133-151.

Granadeiro, J. P., \& Silva, M. A. (2000) The Use of Otoliths and Vertebrae in the Identification and Size-Estimation of Fish in Predator-Prey Studies. Cybium, 24, 383-393.

Harrison, T. (2011). Coprolites: Taphonomic and Paleoecological Implications. In: Harrison, T., Eds., Paleontology and Geology of Laetoli: Human Evolution in Context (pp. 279-292). Vertebrate Paleobiology and Paleoanthropology Series, Dordrecht: Springer. https://doi.org/10.1007/978-90-481-9956-3_14

Horrocks, M., \& Irwin, G. J. (2003). Pollen, Phytoliths and Diatoms in Prehistoric Coprolites from Kohika, Bay of Plenty, New Zealand. Journal of Archaeological Science, 30, 13-20. https://doi.org/10.1006/jasc.2001.0714

http://www.scirpus.ca/dung/mammal.php

http://www.volkovi.si/wp-content/uploads/2014/10/zimsko-sledenje_navodila-koncna.pd $\underline{\mathrm{f}}$

Hüster-Plogmann, H. (2004). Fischfang und Kleintierbeute. Ergebnisse der Untersuchung von Tierresten aus den Schlämmproben. In S. Jacomet, U. Leuzinger, \& J. Schibler (Eds.), Die jungsteinzeitliche Seeufersiedlung Arbon/Bleiche 3, Umwelt und Wirtschaft. Archäologie im Thurgau 12 (pp. 253-276). Kanton: Huber \& Co AG.

Iñiguez, A. M., Araújo, A., Ferreira, L. F., \& Vicente, A. C. P. (2003). Analysis of Ancient DNA from Coprolites: A Perspective with Random Amplified Polymorphic DNAPolymerase Chain Reaction Approach. Mem. Inst. Oswaldo Cruz, 98/1.

Ismail-Meyer, K., \& Rentzel, P. (2004). Mikromorphologishe Untersuchung der Schichtabfolge. In S. Jacomet, U. Leuzinger, \& J. Schibler (Eds.), Die jungsteinzeitliche Seeufersiedlung von Arbon Bleiche 3, Umwelt und Wirtschaft. Archäologie im Thurgau 12 (pp. 66-80). Frauenfeld.

Jacomet, S., Leuzinger, U., \& Schibler, J. (2004). Die jungsteinzeitliche Seeufersiedlung Arbon/Bleiche 3. Umwelt und Wirtschaft. Archäologie im Thurgau 12 (pp. 1-458). 
Kanton: Huber \& Co AG.

Janssens, L., Giemsch, L., Schmitz, R., Street, M., \& Van Dongen, S. (2018). A New Look at an Old Dog: Bonn-Oberkassel Reconsidered. Journal of Archaeological Science, 92, 126-138. https://doi.org/10.1016/j.jas.2018.01.004

Jones, A. K. G. (1986). Fish Bone Survival in the Digestive Systems of the Pig, Dog and Man: Some Experiments. In D. C. Brinkhuizen, \& A. T. Clason (Eds.), Fish and Archaeology, Studies in Osteometry, Taphonomy, Seasonality and Fishing Methods (pp. 53-61). BAR International Series 294.

Jones, A. K. G. (1990). Coprolites and Faecal Concretions. In M. Bell (Ed.), Brean down Excavations (1983-1987) (pp. 242-245). Archaeological Report No. 15, London: Historic Buildings and Monuments Commission for England.

Jörg, S. (2006). The Economy and Environment of the 4th and 3rd Millennia BC in the Northern Alpine Foreland Based on Studies of Animal Bones. Environmental Archaeology, 11, 49-64.

Jouy-Avantin, F. (2003). A Standardized Method for the Description and the Study of Coprolites. Journal of Archaeological Science, 30, 367-372.

https://doi.org/10.1006/jasc.2002.0848

Kottelat, M., \& Freyhof, J. (2007). Handbook of European Freshwater Fishes. Berlin: Kottelat Cornol, Switzerland and Freyhof.

Kreuz, A., \& Schäfer, E. (2011). Weed Finds as Indicators for the Cultivation Regime of the Early Neolithic Bandkeramik Culture? Vegetation History and Archaeobotany, 20, 333-348.

Kühn, M., Maier, U., Herbig, C., Ismail-Meyer, K., Le Bailly, M., \& Wick, L. (2013). Methods for the Examination of Cattle, Sheep and Goat Dung in Prehistoric Wetland Settlements with Examples of the Sites Alleshausen-Täschenwiesen and Alleshausen-Grundwiesen (around cal 2900 BC) at Lake Federsee, South-West Germany. Journal of Environmental Archaeology, 18, 43-57. https://doi.org/10.1179/1461410313Z.00000000017

Le Bailly, M., Leuzinger, U., \& Bouchet, F. (2003). Dioctophymidae Eggs from Coprolites from Neolithic Site of Arbon-Bleiche 3 (Switzerland). Journal of Parasitology, 89, 1073-1076. https://doi.org/10.1645/GE-3202RN

Le Bailly, M., Leuzinger, U., Schlichtherle, H., \& Bouchet, F. (2005). Diphyllobothrium: Neolithic Parasite? Journal of Parasitology, 91, 957-959.

Macphail, R. I. (2000). Soils and Microstratigraphy: A Soil Micromorphological and Micro-Chemical Approach. In A. J. Lawson (Ed.), Animal Husbandry in Later Prehistoric Wiltshire (pp. 47-71). Salisbury: Wessex Archaeology.

Maicher, C., Hoffmann, A., Côté, N. M. L., Palomo Pérez, A., Saña Segui, M., \& Le Bailly, M. (2017). Paleoparasitological Investigations on the Neolithic Lakeside Settlement of La Draga (Lake Banyoles, Spain). Holocene, 27, 1659-1668. https://doi.org/10.1177/0959683617702236

Martin, P. S., \& Sharrock, F. W. (1964). Pollen Analysis of Prehistoric Human Feces: A New Approach to Ethnobotany. American Antiquity, 30, 168-180. https://doi.org/10.2307/278848

Schmid, E. (1972). Atlas of Animal Bones for Prehistorians, Archaeologists and Quaternary Geologists. Amsterdam, London, New York: Elsevier Publishing Company.

Skrbinšek, T. (2010). Navodila za sodelovanje pri raziskavi volkov s pomočjo genetike. Ljubljana: Univerza v Ljubljani, Biotehniška fakulteta, Oddelek za biologijo. http://www.volkovi.si/wp-content/uploads/2014/10/brosura-genetika-slowolf-web1.pdf 
Tolar, T., Jacomet, S., Velušček, A., \& Čufar, K. (2011). Plant Economy at a Late Neolithic Lake Dwelling Site in Slovenia at the Time of the Alpine Iceman. Vegetation History and Archaeobotany, 20, 207-222. https://doi.org/10.1007/s00334-010-0280-0

Torke, W. (2000). Fischreste aus den neolithischen Moorsiedlungen Henauhof I Hartöschle am Feedersee und aus weiteren Fundplätzen Oberschwabens. Berichte zu Ufer-und Moorsiedlungen Südwestdeutschlands III. Materialh, Arch. Baden-Württemberg, 52, 345-357.

Velušček, A. (2004). Past and Present Lake-Dwelling Studies in Slovenia. Ljubljansko Barje (the Ljubljana Marsh). In F. Menotti (Ed.), Living on the Lake in Prehistoric Europe, 150 Years of Lake-Dwelling Research (pp. 69-82). London and New York: Routledge.

Velušček, A., Podpečan, B., Tolar, T., Toškan, B., Turk, J., Merela, M., \& Čufar, K. (2018). Črnelnik and Devce, Newly Discovered Copper Age Sites at Ljubljansko Barje. Arheološki Vestnik, 69, 9-68. 